\title{
Short communication: Improved method for centrifugal recovery of bacteria from raw milk applied to sensitive real-time quantitative PCR detection of Salmonella spp. ${ }^{1}$
}

\author{
Jeffrey D. Brewster*2 and Moushumi Paul† \\ *Molecular Characterization of Foodborne Pathogens Research Unit, and \\ †Dairy and Functional Foods Research Unit, USDA, Agricultural Research Service, North Atlantic Area, Eastern Regional Research Center, \\ Wyndmoor, PA 19038
}

\begin{abstract}
Centrifugation is widely used to isolate and concentrate bacteria from dairy products before assay. We found that more than $98 \%$ of common pathogenic bacteria added to pasteurized, homogenized, or pasteurized homogenized milk were recovered in the pellet after centrifugation, whereas less than $7 \%$ were recovered from raw milk. The remaining bacteria partitioned into the cream layer of raw milk within 5 min, and halfsaturation of the cream layer required a bacterial load of approximately $5 \times 10^{8} \mathrm{cfu} / \mathrm{mL}$. Known treatments (e.g., heat, enzymes or solvents) can disrupt cream layer binding and improve recovery from raw milk, but can also damage bacteria and compromise detection. We developed a simple, rapid agitation treatment that disrupted bacteria binding to the cream layer and provided more than $95 \%$ recovery without affecting bacteria viability. Combining this simple agitation treatment with a previously developed real-time quantitative PCR assay allowed the detection of Salmonella spp. in raw milk at $4 \mathrm{cfu} / \mathrm{mL}$ within $3 \mathrm{~h}$. To our knowledge, this is the first report of an effective method for achieving high centrifugal recovery of bacteria from raw milk without impairing bacterial viability.
\end{abstract}

Key words: raw milk, bacteria, partitioning, recovery

\section{Short Communication}

Foodborne illness associated with raw milk and raw milk products continues to be a significant public health issue in the United States and Europe (Claeys et al., 2013), spurring the development of rapid, sensitive methods to detect bacterial pathogens in these foods.

\footnotetext{
Received March 30, 2015.

Accepted October 22, 2015.

${ }^{1}$ Mention of trade names or commercial products in this publication is solely for the purpose of providing specific information and does not imply recommendation or endorsement by the US Department of Agriculture.

${ }^{2}$ Corresponding author: jeffrey.brewster@ars.usda.gov
}

Two recent studies involving the present authors (Paul et al., 2013, 2015) reported real-time quantitative PCR (qPCR) assays for Escherichia coli $\mathrm{O} 157$ and Listeria monocytogenes in raw milk that used centrifugation to isolate the target bacteria and allowed the detection of $1 \mathrm{cfu} / \mathrm{mL}$ in a few hours. In this protocol, as in many others, the cream and skim-milk fractions were removed from the centrifuged sample, leaving a highly concentrated bacteria pellet largely free of matrix constituents that can interfere with detection. We inoculated the samples immediately before centrifugation to minimize growth during processing, and the recovery of bacteria in the pellet was high and reproducible. However, later experiments in which centrifugation was delayed resulted in low and inconsistent recovery from raw milk (although recovery from pasteurized homogenized milk remained high). Analysis showed that most of the bacteria were in the cream layer of the raw milk rather than in the pellet, indicating that our assay would fail to detect bacteria at the claimed detection limit in naturally contaminated raw milk. We undertook a series of studies to further understand this problem and identify methods to overcome it.

The partitioning of bacteria into the cream layer of raw milk following gravitational or centrifugal separation has long been known (e.g., Anderson, 1909), although we were unaware of the phenomenon until we observed it. We have not encountered any mention of this issue in the recent literature on the detection of pathogens in raw milk, suggesting that other researchers are also unaware of the problem and its effect on assay sensitivity. Partitioning is attributed largely to antibody-mediated binding of bacteria to milk fat globules (Euber and Brunner, 1984), although additional binding mechanisms (e.g., hydrophobic, lectin-sugar, and lymphocyte mediated) have also been suggested (Atroshi et al., 1983; Sánchez-Juanes et al., 2009; Brisson et al., 2010; Caplan et al., 2013), and research in this area is ongoing (Geer and Barbano, 2014). It is important to note that partitioning of bacteria into the cream layer is distinct from the issue of fully separat- 
ing and removing the lipid fraction from milk samples (Cressier and Bissonnette, 2011).

It is well known that proteases, solvents, and heat disrupt the binding of bacteria to fat globules, resulting in efficient centrifugal recovery of bacteria from treated milk (Wegmüller et al., 1993; Herman et al., 1995; Gésan-Guiziou, 2010; Geer and Barbano, 2014). However, protease treatment can be lengthy, while heat and solvents typically damage the bacteria (Sardessai and Bhosle, 2002; Smelt and Brul, 2014), reducing their viability, exposing nucleic acids to loss or degradation, and compromising subsequent culture or PCR detection steps.

We enumerated bacteria using spread plate and drop plate (Chen et al., 2003) colony counts to characterize the extent, capacity, and kinetics of bacteria partitioning in centrifuged milk. The culture conditions and strains of Escherichia. coli O157:H7, Listeria monocytogenes, and Salmonella enterica used were described in Paul et al., 2013. Cultures of spectinomycin-resistant $E$. coli O157:H7 B6-914-Sm (E. coli S+) and kanamycinresistant Salmonella enterica ssp. enterica serovar Minnesota (S. enterica $\mathrm{K}+$ ) were obtained from Gaylen Uhlich, USDA (Wyndmoor, PA) and used in some experiments to achieve better discrimination against high levels of nontarget organisms. Brain heart infusion broth and agar (all pathogens), Oxford agar base and modified Oxford agar supplement (L. monocytogenes), plate count agar (background flora), XLT4 agar (S. enterica), sorbitol MacConkey agar, and cefixime-tellurite supplement (E. coli) were from Difco (Sparks, MD). For $S$. enterica $\mathrm{K}+$ enumeration, XLT4 was supplemented with $50 \mu \mathrm{g} / \mathrm{mL}$ of kanamycin. For E. coli $\mathrm{S}+$ enumeration, sorbitol MacConkey agar was supplemented with $20 \%$ of the normal level of cefixime-tellurite and $50 \mu \mathrm{g} /$ $\mathrm{mL}$ of spectinomycin.

Fresh raw bovine milk and pasteurized homogenized bovine milk were purchased at local markets, stored at $4^{\circ} \mathrm{C}$ in the original retail container, and used before the printed sell-by dates. For one experiment, bulk raw milk was obtained from a commercial dairy and subjected to homogenization and pasteurization under typical commercial processing conditions in the Dairy Pilot Plant facility of the Eastern Regional Research Center (Philadelphia, PA). For batch-heating experiments, retail raw milk $(400 \mathrm{~mL})$ was heated on a stirring hot plate at $\sim 1^{\circ} \mathrm{C} / \mathrm{min}$, and samples $(2 \times 5 \mathrm{~mL})$ were collected as the temperature reached specified values $\left(40^{\circ} \mathrm{C}, 50^{\circ} \mathrm{C}\right.$, $\left.55^{\circ} \mathrm{C}, 60^{\circ} \mathrm{C}, 70^{\circ} \mathrm{C}, 72^{\circ} \mathrm{C}, 80^{\circ} \mathrm{C}\right)$. High-shear agitation was conducted with an UltraTurrax T-25 mixer (IKA Works, Wilmington, NC) at 15,000 rpm using a 10-mm rotor-stator generator. The sample tube was immersed in an ice-water bath and agitation was in $30 \mathrm{~s}$ bursts separated by 15 -s cooling periods. Intense agitation was also conducted at room temperature in disposable centrifuge tubes using a Vortex Genie 2 mixer (Scientific Industries, Bohemia, NY) equipped with a horizontal shaking platform for 15-mL tubes (Scientific

\section{Extent \& Capacity Kinetics}

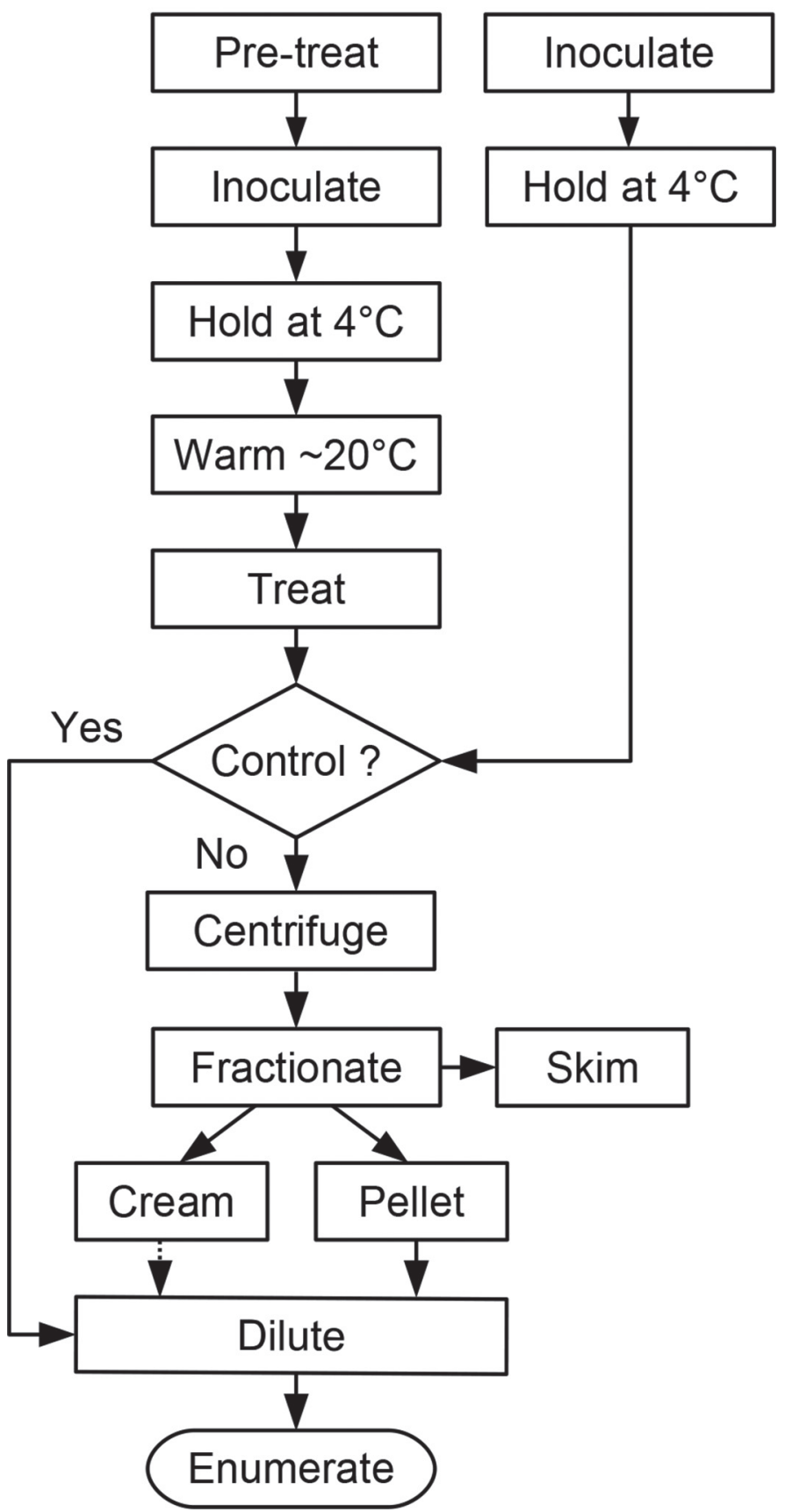

Figure 1. Flowchart for bacteria recovery determination. Pretreatments included heating, pasteurization, homogenization, and freezing. Treatments included EDTA and agitation. See text for details. 
Industries) or 1.5-mL tubes (MO BIO Laboratories, Carlsbad, CA).

The workflow for determining the recovery of bacteria from milk is outlined in Figure 1. For all experiments, cold $\left(4^{\circ} \mathrm{C}\right)$ milk $(1$ or $10 \mathrm{~mL})$ was vortexed briefly with $<0.1$ volume of inocula containing the indicated pathogen(s). Final inoculum levels were $\sim 10^{5} \mathrm{cfu} / \mathrm{mL}$ unless otherwise noted. For kinetic studies, inoculated milk $(1 \mathrm{~mL})$ was held at $4^{\circ} \mathrm{C}$ for varying times $(1-45$ min) and immediately centrifuged at $4^{\circ} \mathrm{C}$ in a fixedangle rotor for $5 \mathrm{~min}$ at $5,000 \times \mathrm{g}$. For other partitioning studies, the samples were held at $4^{\circ} \mathrm{C}$ for at least 1 $\mathrm{h}$, then warmed briefly to room temperature in a $40^{\circ} \mathrm{C}$ water bath. In some experiments, the warm sample was treated with $0.5 M$ EDTA to a final concentration of 40 to $80 \mathrm{~m} M$. Samples in $1.5-\mathrm{mL}$ tubes were centrifuged at room temperature for $5 \mathrm{~min}$ at $5,000 \times \mathrm{g}$ in a fixed-angle rotor; samples in 15 -mL tubes were centrifuged at room temperature for $15 \mathrm{~min}$ at $4,696 \times g$ in a swinging-bucket rotor. Samples were chilled at $4^{\circ} \mathrm{C}$, the cream layer was transferred to a fresh tube with a sterile spatula, and the supernatant liquid was removed by aspiration. Residual cream was removed from the tube walls with a sterile cotton swab moistened with ethanol, and the pellet and cream layer were resuspended to the initial sample volume in saline containing 0.1\% Tween-20. Control samples were inoculated but not centrifuged or fractionated. Samples were serially diluted in saline containing $0.1 \%$ Tween-20 to $\sim 10^{3}$ $\mathrm{cfu} / \mathrm{mL}$ and enumerated on solid medium. Recovery was calculated from the ratio of enumerated colonyforming units in the pellet and cream fractions of the same sample or from the pellet fraction of one sample and the mean total colony-forming units of the control samples.

The sample treatment and qPCR detection protocol described previously (Paul et al., 2013) was followed.
Briefly, samples were treated with EDTA, centrifuged, and the pellet treated sequentially with SDS, DNase, and trypsin, followed by direct DNA extraction in a total volume of $12 \mu \mathrm{L}$ and $\mathrm{qPCR}$ assay in a total volume of $20 \mu \mathrm{L}$. Four modifications were made to the protocol: (a) samples $(10 \mathrm{~mL})$ were inoculated while cold and held at $4^{\circ} \mathrm{C}$ for at least $1 \mathrm{~h}$; (b) after warming and EDTA addition, samples were agitated 10 min at maximum speed on the horizontal shaking platform; (c) $12 \mu \mathrm{L}$ of lysis solution was used and 6 $\mu \mathrm{L}$ of DNA extract was assayed; and (d) Salmonella genus-specific primers and probes targeting the invA gene (Hein et al., 2006) with annealing and extension at $64^{\circ} \mathrm{C}$ were used. The sequences and final concentrations were as follows: forward primer 5'-GTGAAATAATCGCCACGTCGGGCAA-3', $500 \mathrm{n} M$; reverse primer $5^{\prime}$-TCATCGCACCGTCAAAGGAACC-3', 500 n $M$; and probe 5'-HEX-TTATTGGCGATAGCCTGGCGGTGGGTTTTGTTG-IaBkFQ-3', 250 n $M$.

As seen in Table 1, the tested bacteria were partitioned almost fully into the cream layer of raw milk upon centrifugation at room temperature. Partitioning was disrupted by homogenization and pasteurization, but not by freezing. Batch heating of raw milk did not significantly reduce partitioning until the temperature was raised above $70^{\circ} \mathrm{C}$ (data not shown). As shown in Table 2, partitioning was very rapid, with more than $80 \%$ of added bacteria partitioned into the cream layer within 5 min of inoculation, and over $95 \%$ partitioned after $45 \mathrm{~min}$. Recovery remained constant for samples held at $4^{\circ} \mathrm{C}$ for 1,24 , and $48 \mathrm{~h}$ before centrifugation (data not shown). The cream layer also exhibited a high capacity for bacteria (Table 3), reaching half-saturation at a bacterial load of approximately $5 \times 10^{8} \mathrm{cfu} / \mathrm{mL}$. It would require very high levels of nontarget bacteria to saturate the cream layer and fully release the target organisms for centrifugal recovery.

Table 1. Partitioning of bacteria in milk

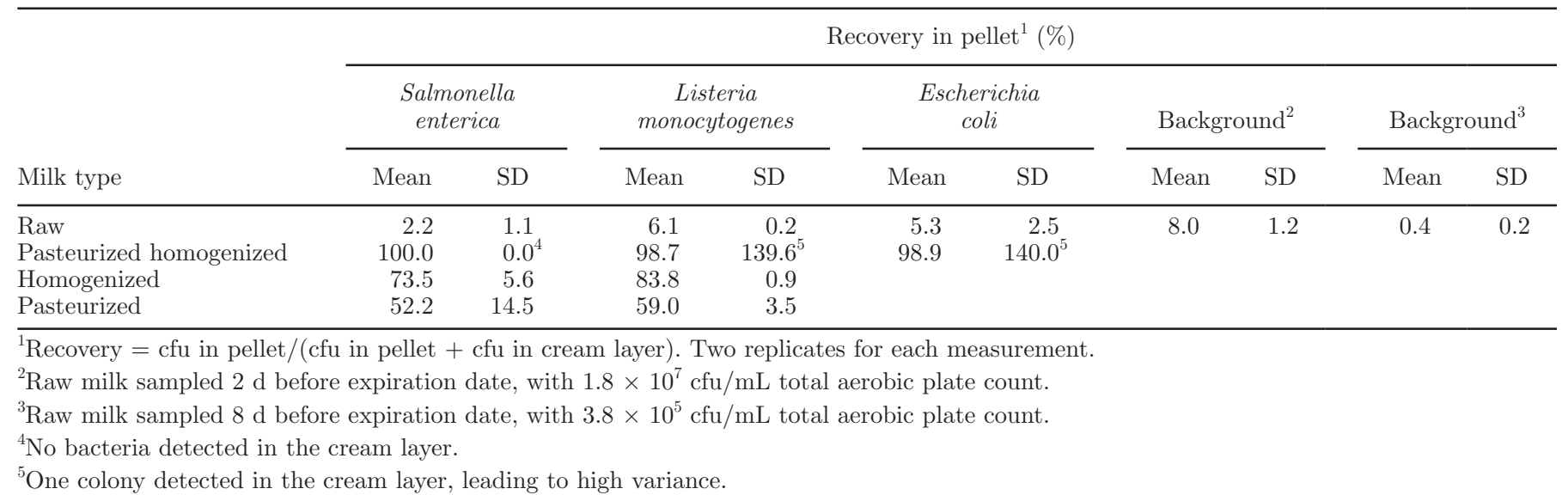


Table 2. Kinetics of bacteria partitioning in raw milk ${ }^{1}$

\begin{tabular}{lccccc}
\hline & \multicolumn{3}{c}{ Recovery in pellet (\%) } \\
\cline { 2 - 3 } & \multicolumn{2}{c}{$\begin{array}{c}\text { Salmonella } \\
\text { enterica }\end{array}$} & & \multicolumn{2}{c}{$\begin{array}{c}\text { Listeria } \\
\text { monocytogenes }\end{array}$} \\
\cline { 2 - 3 } \cline { 5 - 6 } $\begin{array}{l}\text { Incubation } \\
\text { time (min) }\end{array}$ & Mean & SD & & Mean & SD \\
\hline 1 & 62 & 17 & & 38 & 9 \\
5 & 13 & 2 & & 16 & 2 \\
12 & 14 & 2 & & 14 & 8 \\
25 & 6 & 1 & & 6 & 5 \\
45 & 1 & 1 & 4 & 3
\end{tabular}

${ }^{1}$ Recovery $=\mathrm{cfu}$ in pellet/cfu in control. Two replicates for each measurement.

\section{Effect of Agitation on Partitioning}

We attempted to reproduce the effects of process-scale homogenization in the laboratory by agitating raw milk with a high-shear mixer. Agitation of 10-mL samples for 2 to 3 min led to formation of a yellow liquid with the appearance of melted butter, suggesting that milk fat globules were aggregating. Bacteria were efficiently recovered in the pellet after centrifugation of the agitated milk, with the yellow liquid constituting $\sim 40 \%$ of the cream layer (data not shown). Although effective, this approach required processing each sample individually and cleaning the mixer between each sample. It also carried significant risk of aerosol production and carryover. Intense agitation of 1-mL samples of raw milk in 1.5-mL microfuge tubes on a horizontal-axis sample platform produced similar changes in the cream layer and also yielded efficient centrifugal recovery without alteration of bacterial viability. The horizontal orientation of the tubes and their location $\sim 8 \mathrm{~cm}$ from the axis of rotation appeared to provide much more intense agitation than conventional vortex mixing. Results of a typical experiment with $S$. enterica are shown in Figure 2. Further investigations were conducted to optimize this process, test recovery of the other pathogens, and

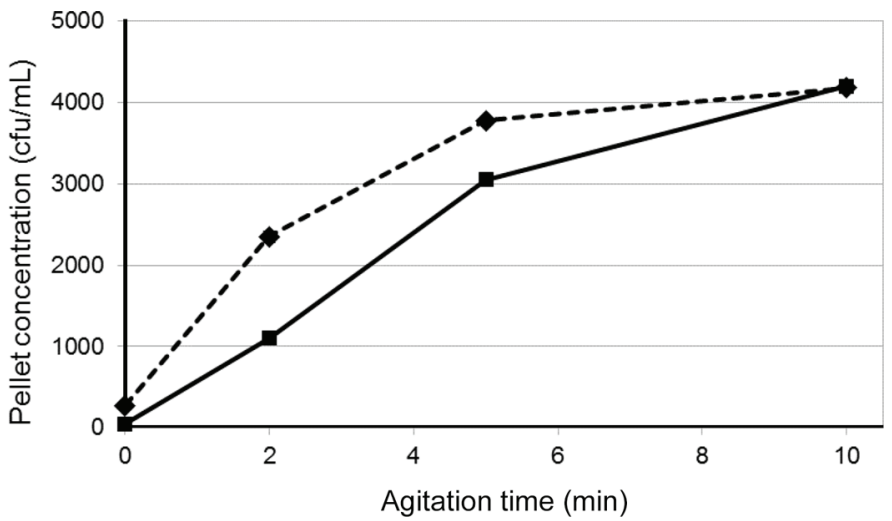

Figure 2. Recovery of Salmonella enterica $\mathrm{K}+$ from agitated raw milk; $1 \mathrm{~mL}$ of raw milk in a $1.5-\mathrm{mL}$ tube was incubated with bacteria, treated with EDTA (where indicated), agitated at maximum speed in a horizontal axis holder for the indicated period of time, centrifuged to recover bacteria, and enumerated by drop plating. Squares, solid line: raw milk. Diamonds, dotted line: raw milk + EDTA, final concentration $40 \mathrm{~m} M$. Standard deviations $(\mathrm{n}=2)$ were less than $100 \mathrm{cfu}$ and were not plotted.

scale up the volume to $10 \mathrm{~mL}$ (data not shown). The final protocol allowed parallel processing of 12 samples in disposable $15-\mathrm{mL}$ centrifuge tubes with no cleaning, aerosol, or carryover issues, using only an inexpensive $(\sim \$ 100)$ sample platform and a common laboratory vortexer.

Addition of the 10-min agitation step to our previous method led to effective recovery of Salmonella inoculated into raw milk, even after hours of incubation at $4^{\circ} \mathrm{C}$. As shown in Table 4, multiple experiments over 3 d gave consistent results with detection of Salmonella spp. at $4 \mathrm{cfu} / \mathrm{mL}$ (20 cfu per reaction) and quantitation from 4 to $420 \mathrm{cfu} / \mathrm{mL}$. Control samples (without milk) gave similar $\mathrm{C}_{\mathrm{T}}$ values, and blank milk samples showed no amplification (data not shown).

Although bacteria are significantly denser than milk and cream, both gram-positive and gram-negative bacteria were rapidly and extensively partitioned into the

Table 3. Bacteria binding capacity of the raw milk cream layer ${ }^{1}$

\begin{tabular}{|c|c|c|c|c|c|c|}
\hline \multirow{3}{*}{$\begin{array}{l}\text { Inoculum, Log (cfu/ } \\
\mathrm{mL})\end{array}$} & \multicolumn{6}{|c|}{ Recovery in pellet (\%) } \\
\hline & \multicolumn{2}{|c|}{$\begin{array}{l}\text { Escherichia } \\
\quad \text { coli } \mathrm{S}+\end{array}$} & \multicolumn{2}{|c|}{ Salmonella enterica $\mathrm{K}+$} & \multicolumn{2}{|c|}{$\begin{array}{c}\text { Listeria } \\
\text { monocytogenes }\end{array}$} \\
\hline & Mean & $\mathrm{SD}$ & Mean & $\mathrm{SD}$ & Mean & $\mathrm{SD}$ \\
\hline 6 & 11 & 10 & 6 & 3 & 11 & 11 \\
\hline 7 & 7 & 2 & 11 & 3 & 10 & 3 \\
\hline 8 & 28 & 3 & 46 & 12 & 12 & 3 \\
\hline 9 & 90 & 19 & 82 & 4 & 81 & 18 \\
\hline
\end{tabular}

${ }^{1}$ Raw milk was inoculated with a mixture containing each of the bacteria at the indicated concentration, held $1 \mathrm{~h}$ at $4^{\circ} \mathrm{C}$, separated by centrifugation, and the pellet fraction enumerated on selective media. Recovery $=\mathrm{cfu}$ in pellet/cfu in control. Two replicates for each measurement. 
Table 4. Reproducibility of threshold cycle values for raw bovine milk spiked with low levels of Salmonella enterica K+

\begin{tabular}{|c|c|c|c|c|c|c|c|c|}
\hline Item & \multicolumn{2}{|c|}{ Trial 1} & \multicolumn{2}{|c|}{ Trial 2} & \multicolumn{2}{|c|}{ Trial 3} & \multicolumn{2}{|c|}{ Trial 4} \\
\hline \multicolumn{9}{|c|}{ Spiked raw milk ${ }^{1}(\mathrm{cfu} / \mathrm{mL})$} \\
\hline 42 & 32.9 & 0.6 & 33.0 & 0.2 & 34.0 & 0.6 & 33.1 & 0.2 \\
\hline 420 & 29.6 & 0.1 & 29.0 & 0.4 & 30.4 & 0.3 & 30.2 & 2.1 \\
\hline \multicolumn{9}{|c|}{ Controls, bacteria only, no milk $^{2}(\mathrm{cfu} / \mathrm{mL})$} \\
\hline 420 & 29.8 & 0.1 & 29.4 & 0.5 & 28.9 & 0.4 & 28.9 & 0.2 \\
\hline
\end{tabular}

${ }^{1}$ Three replicates at each concentration. No amplification was detected in unspiked samples.

${ }^{2}$ Bacteria in saline were collected by centrifugation and subjected to DNA extraction. Two replicates at each concentration.

cream layer upon centrifugation of raw milk, preventing efficient recovery and concentration of the organisms in the sediment (pellet). Intense agitation in closed tubes provided a simple, rapid, and effective solution to this problem, while avoiding damage to the bacteria characteristic of other treatments (e.g., heat or solvents). Addition of an agitation step to our previous method for detection of bacteria in raw milk provided rapid, sensitive detection of $S$. enterica in samples simulating naturally occurring contamination. This modification can provide a uniform sample treatment protocol for all types of milk and improve recovery in any assay utilizing centrifugal recovery of bacteria from raw milk.

\section{ACKNOWLEDGMENTS}

The authors acknowledge David Barbano (Department of Food Science, Cornell University, Ithaca, NY) for his valuable comments and advice, and Raymond Kwoczak (USDA-ARS-NAA-ERRC) for technical assistance. This research was funded under USDA-ARS Project no. 8072-42000-071-00.

\section{REFERENCES}

Anderson, J. F. 1909. The relative proportion of bacteria in top milk (cream layer) and bottom milk (skim milk), and its bearing on infant feeding. J. Infect. Dis. 6:392-400.

Atroshi, F., T. Alaviuhkola, R. Schildt, and M. Sandholm. 1983. Fat globule membrane of sow milk as a target for adhesion of K88positive Escherichia coli. Comp. Immunol. Microbiol. Infect. Dis. 6:235-245.

Brisson, G., H. F. Payken, J. P. Sharpe, and R. J. Jiminez-Flores. 2010. Characterization of Lactobacillus reuteri interaction with milk fat globule membrane components in dairy products. J. Agric. Food Chem. 58:5612-5619.

Caplan, Z., C. Melilli, and D. M. Barbano. 2013. Gravity separation of fat, somatic cells, and bacteria in raw and pasteurized milks. J. Dairy Sci. 96:2011-2019.
Chen, C. Y., G. W. Nace, and P. L. Irwin. 2003. A 6x6 drop plate method for simultaneous colony counting and MPN enumeration of Campylobacter jejuni, Listeria monocytogenes, and Escherichia coli. J. Microbiol. Methods 55:475-479.

Claeys, W. L., S. Cardoen, G. Daube, J. De Block, K. Dewettinck, K. Dierick, L. De Zutter, A. Huyghebaert, H. Imberechts, P. Thiange, Y. Vandenplas, and L. Herman. 2013. Raw or heated cow milk consumption: Review of risks and benefits. Food Contr. 31:251-262.

Cressier, B., and N. Bissonnette. 2011. Assessment of an extraction protocol to detect the major mastitis-causing pathogens in bovine milk. J. Dairy Sci. 94:2171-2184.

Euber, J. R., and J. R. Brunner. 1984. Reexamination of fat globule clustering and creaming in cow's milk. J. Dairy Sci. 67:2821-2832.

Geer, S. R., and D. M. Barbano. 2014. The effect of immunoglobulins and somatic cells on the gravity separation of fat, bacteria, and spores in pasteurized whole milk. J. Dairy Sci. 97:2027-2038.

Gésan-Guiziou, G. 2010. Removal of bacteria, spores and somatic cells from milk by centrifugation and microfiltration techniques. Pages 349-372 in Improving the Safety and Quality of Milk. Volume 1: Milk Production and Processing. M. W. Griffiths, ed. Woodhead Publishing Ltd., Cambridge, UK.

Hein, I., G. Flekna, M. Krassnig, and M. Wagner. 2006. Real-time PCR for the detection of Salmonella spp. in food: An alternative approach to a conventional PCR system suggested by the FOODPCR project. J. Microbiol. Methods 66:538-547.

Herman, L. M., J. H. De Block, and R. J. Moermans. 1995. Direct detection of Listeria monocytogenes in 25 milliliters of raw milk by a two-step PCR with nested primers. Appl. Environ. Microbiol. 61:817-819.

Paul, M., G. M. Baranzoni, S. Albonetti, and J. D. Brewster. 2015. Direct, quantitative detection of Listeria monocytogenes in fresh raw whole milk by qPCR. Int. Dairy J. 41:46-49.

Paul, M., D. L. Van Hekken, and J. D. Brewster. 2013. Detection and quantitation of Escherichia coli $\mathrm{O} 157$ in raw milk by direct qPCR. Int. Dairy J. 32:53-60.

Sánchez-Juanes, F., J. M. Alonso, L. Zancada, and P. Hues. 2009. Glycosphingolipids from bovine milk and milk fat globule membranes: A comparative study. Adhesion to enterotoxigenic Escherichia coli strains. Biol. Chem. 390:31-40.

Sardessai, Y., and S. Bhosle. 2002. Tolerance of bacteria to organic solvents. Res. Microbiol. 153:263-268.

Smelt, J. P. P. M., and S. Brul. 2014. Thermal inactivation of microorganisms. Crit. Rev. Food Sci. Nutr. 54:1371-1385.

Wegmüller, B., J. Lüthy, and U. Candrian. 1993. Direct polymerase chain reaction detection of Campylobacter jejuni and Campylobacter coli in raw milk and dairy products. Appl. Environ. Microbiol. 59:2161-2165. 